\title{
乾田直播栽培を軸とした水稲の大型機械化 一貫作業体系確立に関する研究
}

\author{
新潟農業試験場：橋本良材・泉田又蔵・ \\ 大柣裕一・金山洋
}

\begin{abstract}
Yoshiki HASHIMOTO, Matazo IZUMIDA, Yuichi OTSUKI and Hiroshi KANAYAMA : Studies on the Mechanized Work System of the Through Process in Rice Culture Practice by the Use of Large Machines in Direct-sowing on the Dry Paddy Fields.
\end{abstract}

\section{1. はしがき}

生産者米価のすえ置さ，生産調整など米に関する 状勢が一変し, 稲作に対し労働生産性の向上とコス トダゥンが強く要請されてきた。従来, 省力技術と して直播栽培や除草剤利用体系などがあり，省力の効 果を一応あげてをた。最近では田植機およびバイン ダーや自脱型コンバインが急速に伸びてをて一層省 力になった。大型機械化䅛作についてはいろいろ検 討されているが， いまだ多くの問題をかかえている。 筆者らは基盤整備に伴なら水稲の大型機械化一貫技 術体系を樹立するため, 昭和 38 年以降乾田直播を 軸として，かんがん，除草法，施肥法など一連の基 礎試験を行なってきた。昭和 44 年, 組立試験とし て大区画圃場での大型機械化一貫作業体系試験を実 施した。今後，なお解明を要する点も少なくないが 本報においては主として調査結果の概要と問題点を 報告する。

\section{2. 調查方法。}

\section{1）試験実施場所}

新潟県中蒲原郡亀田町鵜ノ子（新潟農試阿賀野川 試験地亀田再場 )

2 ）試験実施圃場の区画と面積

\section{長辺 $180 \mathrm{~m}$ 短辺 $72 \mathrm{~m}$ 約 $1.3 \mathrm{ha}$}

3 ）試験実施圃場の立地条件

信濃川，阿賀野川，小阿賀野川によって囲まれた 輪中地带の亀田郷に位置する沖積層埴壌土水田で, その標高はー $17 \mathrm{~cm}$ の低地である。試験圃場の概況 を第 1 図に示した。従前の20a区画の畦畔をつぶし 特に田面高低の均平は行なわないで 1 筆に区画を拡大 した。かんがら施設は従前の用水体系を利用し，さ
らに大区画圃場でのかんがんを容易にする目的で圑 場排水路の末端に止水堰を設け，かんがい時には排 水路の水位をコントロールでをるようにした。排水 施設は昭和 30 年に暗渠排水工事が行なわれており, 大区画固場の造成時に幹線用水路側のトラクタ一旋 回場所へ梁さ $50 \mathrm{~cm}$ の浅々暗渠を埋設して, 地耐力 の強化をはかった。

\section{4 ) 供試機械}

体系試験に使用した機械は第 1 表のようである。

\section{3. 調査結果と考察}

目標収量ha当り精玄米重 $5000 \mathrm{~kg}$ ，計画延作業時間

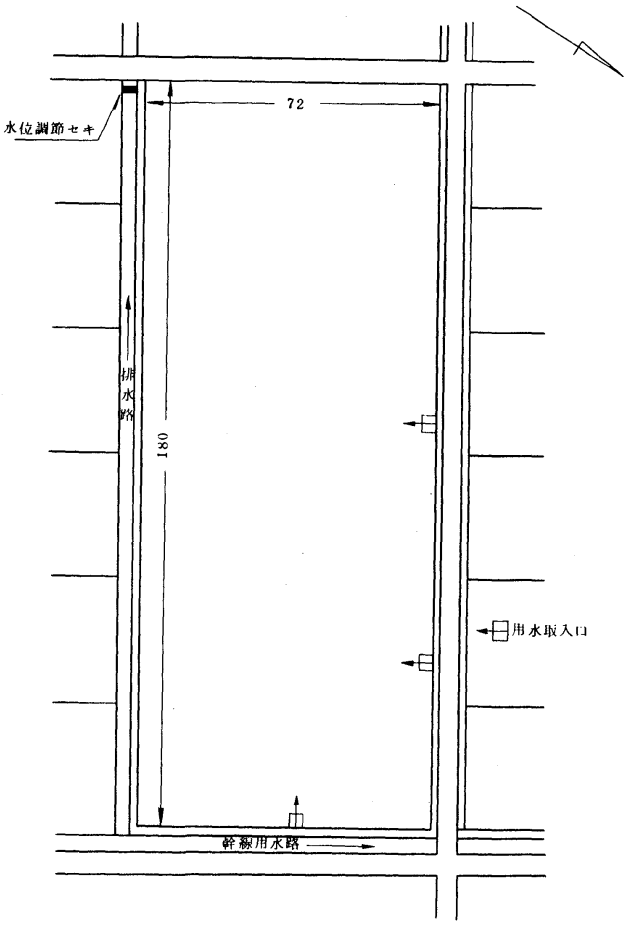

第 1 図 試験活場の平面図 
第 1 表 供試機械

\begin{tabular}{|c|c|c|}
\hline 㙨 械 名 & 式 & 大きさ \\
\hline 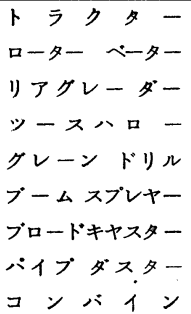 & $\begin{array}{l}\text { フイアツト } 450 \\
\text { R S B - } 1600 \\
\text { MT H - } 303 \\
\text { MGD. } 7 \\
\text { 試作僟 } \\
\text { HC B - } 2 \\
\text { M } 200 \mathrm{R}\end{array}$ & $\begin{array}{l}45 \mathrm{PS} \\
1.5 \mathrm{~m} \\
1.5 \mathrm{~m} \\
3.42 \mathrm{~m} \\
1.5 \mathrm{~m} \\
\text { ブームノズル } 10 \mathrm{~m} \\
\text { 散布巾 } 10 \mathrm{~m} \\
\text { 多口噴管 } 30 \mathrm{~m} \\
\text { 则巾 } 2.3 \mathrm{~m}\end{array}$ \\
\hline
\end{tabular}

$72 \cdot 6$ 時間で試験を始めた。その結果は次のようで ある。

\section{1) 所要時間}

各作業種目別の所要時間を第 2 表に示した。ha当 り総延作業時間は 51.3 時間と計画時間を割り, 現 行稲作に比べ大幅に省力化された。これを作業工程 別に分類すると第 2 図のようになる。作業時間を著 しく短縮し得た最大の原因は，体系内の除草効果が 高く，しかも作業方法が高能率的であったととと， 固場の区画拡大によって, 各作業種目とも効率的に

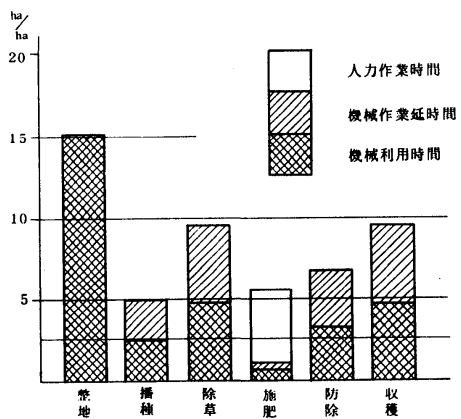

第 2 図 作業工程別所要時間

行なわれたてとがあげられる。これまで乾田直播栽 培の問題点とされていたヒエ抜さ作業が解消された こと,および機械利用が全体の $91 \%$ 占めたてとが 本体系の特幑と云えよう。第 3 図に見られるように 作業のピークは 4 月下旬〜 5 月上旬に現われる。機 械特にトラクターの合理的な運用の検討が必要であ ろう。本体系は種粐予措, 水管理, 収穫物運搬と乾 燥調整の作業種目を除々て調査した。種粐予措は屋 内作業であり, 事前に処理される事項であるので省 いた。水管理につんては排水路堰上げだけでほとん

第 2 表 大型機械化一貫作業体系試験所要労力集録表

( $h a$ 当り)

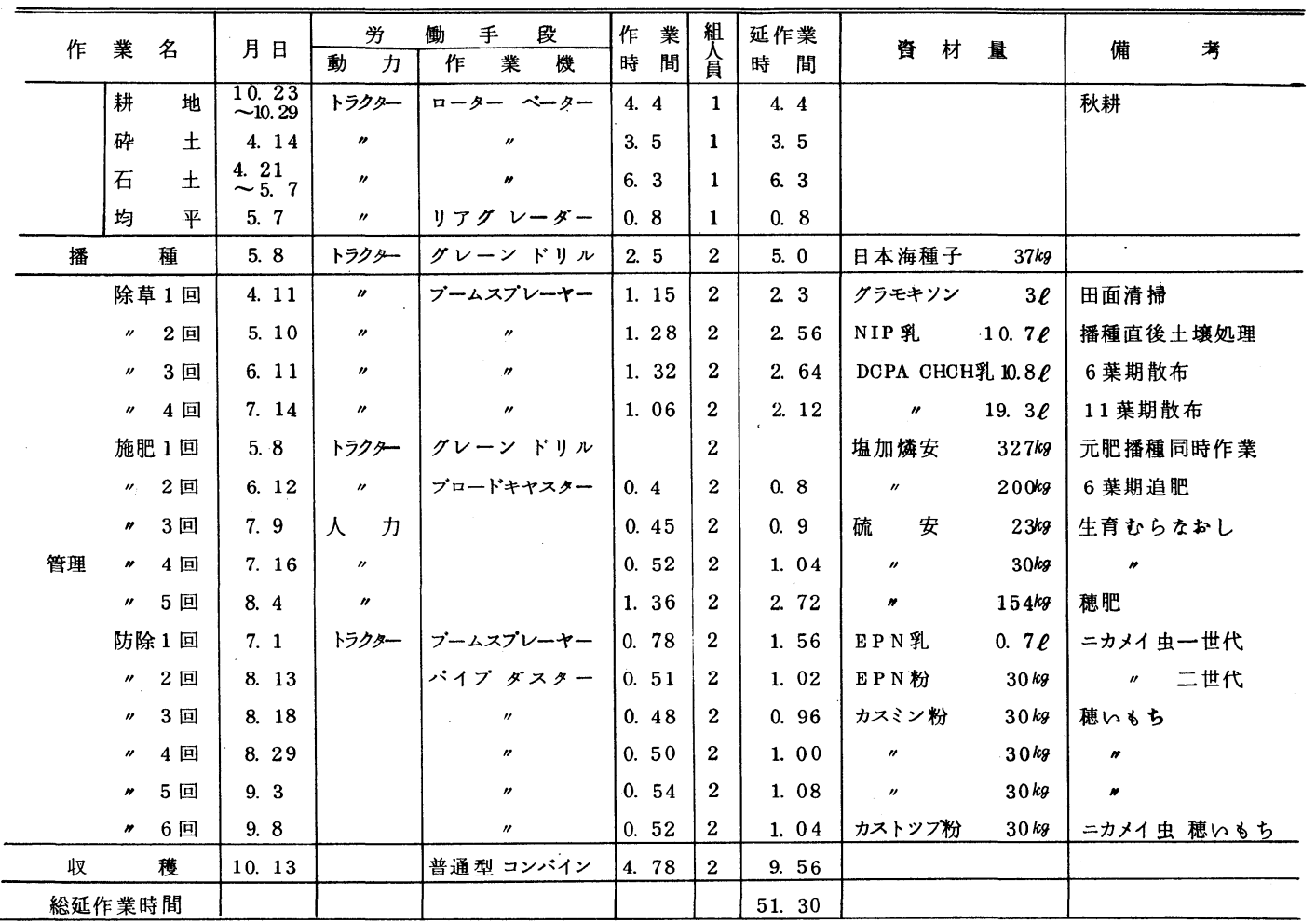




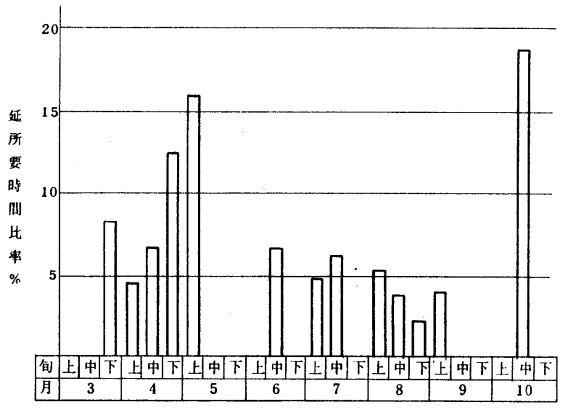

第 3 図 月別作業時間

ど時間らしん時間を要せず，をた調査基準が不明確 で労力の判定がむずかしんので調査外とした。収穫 物運搬と乾燥調整は击場からライスセンタ一をでの 距離と運搬に用いる車種によって異なり，をたイ スセンタ一の規模や性能のいかんによって左右され るからてれる調査から除外した。以上のように, 本 体系は圃場での実作業について検討したものである。

2 ) 各作業種目別の概要と問題点

(1) 整地作業

大区画圑場造成の初年目は圑場前歷の違いによっ て土壤の乾燥状態が異なり, 整地を均一にすること は困難であった。しかも，砕土作業の直前に不測の 用水路からの浸水を受けた。乙の場合, ッース八ロ 一よりリアグレーダーの利用が効果的であった。砕 土率加見た整地の判定基準を土塊径 $3 \mathrm{~cm}$ 以下 $80 \%$ とすると, 第 4 図のように前年度乾田直播栽培跡地 は1回の研土で良好な精度が得られた。したがって 耕耘整地の作業は年を経るどとに容易になるととが 推察される。第 5 図に示すよらに重粘土水田におい てもプラウによる秋耕などが考慮されるならば, 整地 がより容易になるととが推測される。ロータリ一耕 プラウ耕ともそれぞれ一長一短があり，耕耘方式を 一概には定められないが，てれらの長所をらまく利 用するととが必要であろら。ッースハローによる均 平作業は田面の凹凸をならすととに加えて, 耕耘後 の播種床附近を粗な状態から密な状態にし, 播種床 の毛管現象を有利にするとと，作土層がしまってそ の後のトラクターの固場での走行を容易ならしめる ことから，乙れはこの体系には必要な作業種目と考 えられる。

(2) 播種作業。

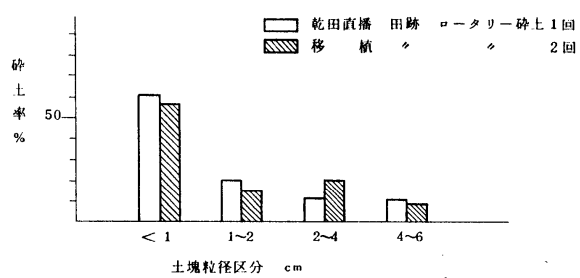

第 4 図㴗場前歴と砕土状態



第 5 図 秋耕と砕土状態

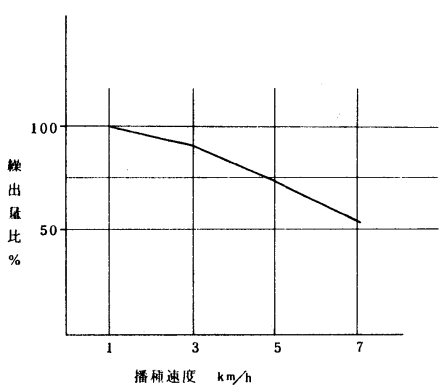

第 6 図 播種速度と操出量

播種作業が能率よく精度高く実施でさるか否かは 整地の良否が大をく影響する。使用した機械は多条 式ドリル播を型式であるが，乙の型式のものは整地 条件さえ良ければ，作業速度 $5 \sim 7 \mathrm{~km}$ 時です精度 高く能率的であった。播種機の繰り出し方式がロ ル円形セルの場合は, 第 6 図に示したように播種速 度によって種粐の繰り出し量が変化するから，7km /時のような高速の場合には，あらかじめ播種口ー ルの変更による速度と播種量の調整が必要である。

(3) 除草作業

第 3 表は作業体系試験での除草作業時間の経年推 
第3 表 除 草 労 力 $の$ 推 移

\begin{tabular}{|c|c|c|c|c|c|c|c|c|}
\hline 年 次 & $\begin{array}{r}\text { ほ埸面積 } \\
\text { a }\end{array}$ & 除 & 草 & 体 & $\begin{array}{c}\text { 除草時間 } \\
\text { 時/ha }\end{array}$ & $\begin{array}{c}\text { 全作業総延時間 } \\
\text { 時 } / \mathrm{la}\end{array}$ & 同 & \\
\hline 41 & 20 & \multicolumn{3}{|c|}{ N I P-D C P A 一手取 $-2.4-D$} & 116. 5 & 201. 6 & & 9 \\
\hline 42 & 40 & \multicolumn{3}{|c|}{ N I P -D C P A一手取 } & 83. 8 & 152. 8 & & 8 \\
\hline 43 & 20 & \multicolumn{3}{|c|}{ N I P -DCPA-D CPA. C HCH } & 55. 0 & 152. 0 & & 2 \\
\hline 44 & 130 & \multicolumn{3}{|c|}{ グラモキソンーN I P ーDC P A , O HCH } & 9. 6 & 51. 3 & & 7 \\
\hline
\end{tabular}

移である。昭和 41 年当初は普通乾田直播栽培に準 じ NIP-DCPH-2.4D の体系をとつたが，除草 効果が不充分なため手取除草に多くの時間を要した。 昭和 43 年以降は $\mathrm{DCPA}-\mathrm{CHCH}$ 乳剤の使用に よって，除草作業は薬剤散布による除草のみによっ て体系づけられ手取除草を排除することができた。 作業方法は水稲の立毛中にもかかわらずトラクタ一 を固場内に乗り入れ、ブームスプレーヤ一による散 布を実施した。乙れが除草効果を大ならしめ省力の

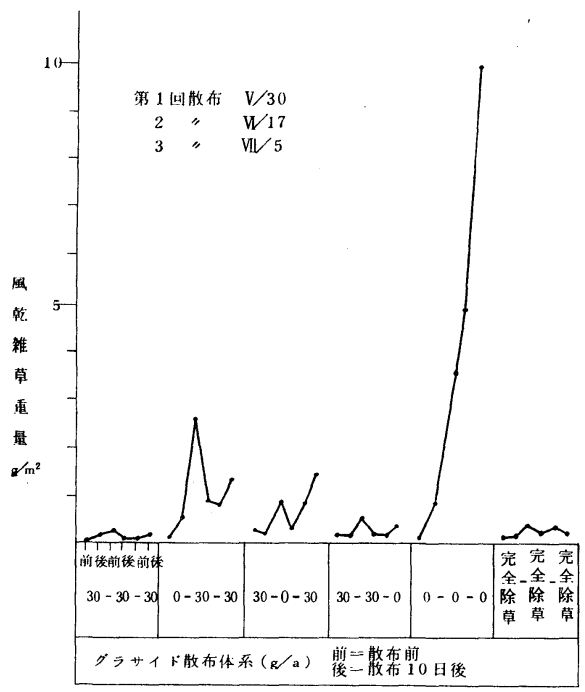

第 7 図 グラサイドによる除草体系別除草効果

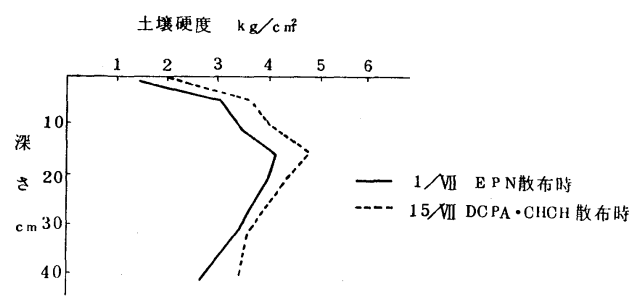

注）SRII 型.七壃硬度䣋を使用

第 8 図 トラクタ一作業時の土壤硬度
原因となった。除草効果は第 7 図に示すようにきわ めて高功。乙の除草体系は落水除草体系である から，落水が早急にでをる固場基盤設備が必要であ る。水稲立毛中の圑場内トラクタ一の走行と水稲の 損傷につルては, 第 8 図に示すような地耐力が強い 場所では, タイヤ踏圧による損傷はすぐ回復して問 題にはならなかった。しかし, 田面が低く落水が不 充分で地耐力の弱い場所では, 作業回数（通算 5 回 ）を増すにつれてタイヤの沈下が梁くなり，沈下梁 さが 10 1 $5 \mathrm{~m}$ 亿なると $40 \mathrm{~cm}$ 幅の溝となって水䅛 に損傷を与えた。

(4) 施肥作業

元肥は播種時にグレーンドリルによって種粐と同 時施用したがさしたる問題はなかった。追肥にはプ ロードキヤスターを用いたが散布幅が 7 〜 $\mathrm{m}$ にと どまり,ブームスプレーヤ一の散布幅 $(10 \mathrm{~m})$ と一 致せず，乙のため帯状の生育むらを生じた。その結 果，2回にわたってむら直し追肥を人力にょって行 なった。穂肥作業も人力で実施した。施肥体系の樹 立が問題である。

(5) 防除作業

7 月中旬頃までの防除作業はブームスプレーヤー による手段が作業能率，精度からして適切な方法と 考えられる。しかし，その後はトラクタ一による水 稲の踏圧損傷を考えると，パイプダスタ一の利用が 考えられる。従来，懸念されていた株元散布を必要 とするメイチュウ 2 化期，紋枯病，ウンカなどに対 しても機械の性能の向上と相まってその使用が考え られる。との体系で固場周辺に特に発生しやすいケ ラの食害と梁水か所に生ずるハモグリバエに注意し なければならない。

(6) 収穫作業

コンバインは走行に問題はなく，また水稲の倒伏 が全くなかったので，スレッシングロスは $4.2 \%$ に 


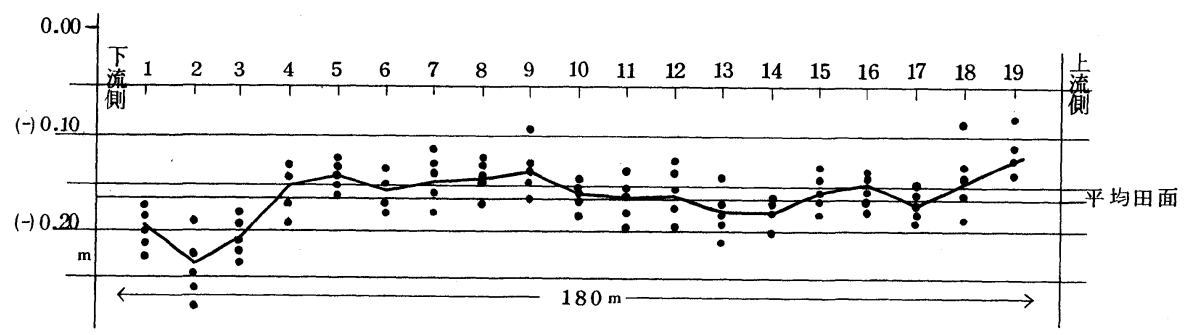

第 9 図汪場の縦断方向における各測点平均標高

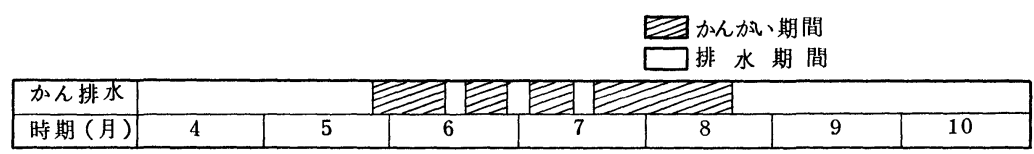

第 10 図 かん排水の基本的操作

とどをり,ha 当り延作業時間は 9.6 時間と著るしく少 なかった。コンバインの導入に伴なって生ずる問題 点として, 土壤の緊密化と残秙処理があげられる。 残秙処理はコンバインチョッパーに上る切断散布方 法が能率的でその後の鋤込みも容易であった。

(7) 田面高低

阑場区画の拡大によって生ずる田面の高低は，あ る程度さけられないるのと見なければならない。固 場整備の策定基準によると, 均平の許容度は土 $5 \mathrm{~cm}$ とされているが，供試した大区画圃場の田面高低状 況は第 9 図のようで, 乙れを高低部面積比率で求め ると, 高位部(標高-13cm以上) $39.4 \%$, 中位部（標 高-8〜 1 20m） $57.7 \%$, 低位部（標高-7om以下）

$7.9 \%$ となり, 最高最低田面差は 240 代あった。て らした高低差は直接に大型機械の作業上に及潘す影 響は少なかった。

（8） 汃排水

かん排水操作が自由にコントロールできるととが 本体系の基本的条条件となる。第 10 図のようなか ん排水を行なった。排水期間中は处部水系とは完全 に遮断することが必要であり，ととに整地から出芽 に至るまでの期間は管理を充分にしなければならな レ。かんがいは用水路からかん水すると同時に排水 路末端の堰を利用して排水路の水位を上界させ，圃 場の地下水位を高める万法をとった。排水について は本暗渠を中心にしてをたが、トラクターやコンバ
第 4 表 水稲の生育収量

\begin{tabular}{|c|c|c|c|c|c|}
\hline 草 & 立 & $54 \pm 27^{\text {本/ } / 2}$ & \multicolumn{2}{|c|}{ 精粐 歩合 } & $45 \%$ \\
\hline \multicolumn{2}{|c|}{ 茥数(7月29日) } & $291 \pm 94$ & \multicolumn{2}{|c|}{ 粗玄米重 } & $396 \pm 62$ \\
\hline H & 穂 期 & 8月 27 日 & \multicolumn{2}{|c|}{ 精玄米重 } & $378 \mathrm{~kg} / 10 \mathrm{a}$ \\
\hline & 舆 & $83 \pm 45 \mathrm{~cm}$ & & $\begin{array}{l}\text { 精 粐 } \\
\text { 精玄米 }\end{array}$ & $\begin{array}{l}28.7 \mathrm{~g} \\
24.7 \mathrm{~g}\end{array}$ \\
\hline 和 & 長 & $21.6 \mathrm{~cm}$ & 登 & 热歩 & $77.7 \%$ \\
\hline 和 & 数 & $\underset{306 \pm 79}{\stackrel{1}{4} / m^{2}}$ & 粒 & $\begin{array}{c}1 \text { 穂 } \\
m^{2} \text { 当 }\end{array}$ & $\begin{array}{l}58 \text { 粒 } \\
177 \times 100 \text { 粒 }\end{array}$ \\
\hline & 粐 重 & $4788 / \mathrm{m}^{2}$ & & & \\
\hline
\end{tabular}

インの走行による土壤の緊密化現象などで, 地表水 の排除に不満な点が認められた。

3 ）水稲の生育収量

本作業体系試験の水稲生育収量は第 4 表のようて ある。播種後用水路からの溢流で圈場内に漫水した ため，田面の低い部分が湛水し発芽障害を招いた部 分があった。また，圃場前歴の違いによる整地良否 が原因して出芽むらとなった部分があった。初期か ん水時をでの降雨量不足で生育が停滞したため生育 量の確保が不充分で，乙れが出穂遅延，穂数不足の 原因となった。さらに，昭和 44 年は 8 月中に日照 不足の異常天候に見舞われ，登熟歩合の低下と千粒 重の减少によって, 精玄米重は10a当り最高 $489 \mathrm{~kg}$ ，最 低243kg で逋場平均は $378 \mathrm{~kg}$ にとどすった。収量と田面つ 高低との関係を見たのが第 5 表である。各部位の収 
第 5 表 田面の高低に伴なら収量の変化

\begin{tabular}{|c|c|c|c|c|}
\hline 田 & 面 & 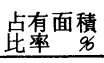 & 項 & $\begin{array}{l}k g / 10 \mathrm{a} \\
\text { 粗玄米重 } \\
\end{array}$ \\
\hline & 3位 & 39 & ${ }^{\text {平 }{ }_{\mathrm{CV} \%} \text { 均 }}$ & $\begin{array}{rl}36 & 68 \\
14.5\end{array}$ \\
\hline & $\begin{array}{l}\text { 位 } \\
\sim-12 \mathrm{~cm})\end{array}$ & 53 & 平 ${ }_{\mathrm{CV} \%}$ 均 & $\begin{array}{rl}4 & 23 \\
1 & 4.7\end{array}$ \\
\hline & $\begin{array}{l}\text { 位 } \\
\text { cm以下) }\end{array}$ & 8 & 平 ${ }_{\mathrm{CV} \%}$ 均 & $\begin{aligned} 355 \\
12.3\end{aligned}$ \\
\hline 全 & 体 & 100 & 平 $\mathrm{cV} \%{ }^{\text {均 }}$ & $\begin{array}{lll}3 & 9 & 6 \\
& 1 & 5.7\end{array}$ \\
\hline
\end{tabular}

量は中部>高部 ミ低部となり，高低部の収量が少な かったため目標収量には達しなかった。今後，大区 画圃場の水稲生育相につんて，かん排水方法と関連 して検討する必要がある。

\section{4. むすび}

以上，調査結果を中心として述べた。組立てられ
る作業体系は経営試算なり経済的評価を経て確立さ れることは当然であろらが，まず技術の組立が先决 となろら。筆者らは, 大型機械化栽培技術の体系化 を目標として研究に取り組み， 1 筆 1.3 ha の大区画 圑場で大型機械の一貫作業を通じ，収量につんては 不満足な結果であったが，総延所要時間 ha当り 50 時間台，収量で 3 等米と 4 等米ha 当り $4000 \mathrm{~kg}$ 近く 収めることがでさた。大型機械化一貫作業体系の確 立は土地基盤整備や栽培法，作業などの技術的な面 と経営とがうまく結合するととによって成立するも のであろら。一応，技術の組立としての大型機械化 一貫稲作の見通しは得られた。この体系を現地の生 産組織集団に導入した場合技術的にどのような問題 が生ずるか経営的評価はどらか今後検討してゆをたい。

\section{用 語 解 説}

（3）䋂営管理 一経営と管理をつないだ語句である が，次のようにんろいろな意味をもっている。 （能率ハンドブック P 96 ）

ア. 広義の管理すなわち経営と管理とををとめた 用語として使う場合。

イ. 経営管理学などと science of industrial management の訳として使う場合。

ウ. administrative management の訳として使ら 場合、経営の管理または経営的営理の意味で国 家機間では行政管理と訳している。

（4）生産管理 ${ }^{3}$ - 所定の品質の製品を所定期间に所 定の数量だけ，期待される原価で生産するように 生産要素である機械, 設備, 原材料, エネルギー および労働が最適能率を発揮するように生産の機 構を設計，計画し，統整・調整を行ならことであ る。普通その内容としては, 組織, 工程, 作業, 工具, 資材, 運搬, 施設, 安全, 衛生, 貨金, 原 価等の管理を意味するととが多い゙をてして生産技 術が進み分業化されるに従って管理項目は増加し, 品質, 計測, 熱, 色彩, 温湿度, 照明等の管理が 加わって来る。

工場にあっては管理の主要部分を占め, 生産に 関係あるものを中心にして管理全体に及んでいる 堨合もあるが, 時には管理を生産営理, 財務管理,
労務管理などに大別することもある。

なお, 労働法上生産管理と称する場合には労働 組合が経営者を排除して事業体の管理をすること を意味する。

\section{(5) 工程管理 ${ }^{3}$}

ア. 狭義には所定の仕様の製品（図面や仕様書で その内容が規定される。）の所定数量（製造命 令で指示される。）を所定の期間（製造命令で指 示される ) に所定の経費で製造するために，

(乃 加工の順序, 方法, 自所加工と外注の区別, 所要の工具, 検査等の手順を决め

(イ) 材料準㑅, 作業の着手・完了など各係相互 の関連した日桯計画を定め

(ウ) 倉厙に対しては所要の原材料, 購入完成部 品等の準備要求をなし，てれが払出しを受け

(エ) あらかじめ準備した各㮔帳菬により，全体 の工作過程のそれぞれについて進行を日程的に 統制し，事故遅延対策を迅速に講ずるととである。 1. 広義の場合には上記の外に

（乃製造工程に先行して行なわれる製品の研究 ならびに設計過程，原材料の購買調達過桯

（イ）製造工程に引続いて行なわれる完成製品が 顧客に引を渡されるまでの販売配給過程の一部 または全部を含む場合がある。 